\title{
AN EVALUATION OF ASSOCIATE DEGREE DISTANCE EDUCATION PROGRAMS IN TERMS OF STUDENT OCCUPANCY RATES
}

\author{
Dr. Eren KESIM \\ Anadolu University \\ Faculty of Education \\ Eskisehir, Turkey
}

\section{ABSTRACT}

This paper will discuss the student occupancy rates between 2007 and 2016 of two-year associate degree distance education programs in Turkey on the basis of both the program and the university and to identify the potential variances. As a result of descriptive analyses, it has been determined that Tour Guiding, Mapping and Cadastral Survey, and Mechatronic programs and Kafkas, Nevşehir Hacı Bektaş Veli and Celal Bayar Universities have the highest occupancy rates. It has been observed during the statistical analyses that the occupancy rates have not varied based on the period during which the program has been open and the university count. Therefore, the hypothesis that the programs opened by many universities or has accepted students for many years have the highest occupancy rate has not been supported. The university-based analyses have demonstrated that the occupancy rates of universities have varied with regard to the total number of years that distance education programs have been opened. Correspondingly, the universities which have opened the programs in more years than others, those having much experience in other words, have higher occupancy rates.

Keywords: Distance education, economics of education, economics of distance education, associate degree programs, occupancy rates, university performance.

\section{INTRODUCTION}

Newly developing technologies have ensured that the initiation of structural changes in higher education institutions is imperative. The education and teaching activities provided at higher education institutions have increasingly been offered within the scope of distance education services through the support of new technologies. This emphasizes the competitive aspect of preparing students for future careers of higher education institutions (Altbach, Reisberg \& Rumbley, 2016).

As all the educational institutions have been affected by the pace of change, it is of utmost importance for higher education institutions to put an intense change period into practice. One of the most important reasons of this necessity is the adaptability of alumni to changing and developing business world. For the very reason, universities have to reconstitute their current structure in order to be able to respond to the expectation of the public in compliance with the rules of knowledge-based society (Boys, 2015).

The development of distance education technologies has increased the interaction between teacher and student during the distance education process, and provided important contributions to the effectiveness of feedback processes in classes (Ferguson, Sharples \& Beale, 2015). As such, rise in the number of distance education programs in personal development and career development at universities is highly significant (Huang, Hsiao \& Lunce, 2014). 
Distance education is a significant example of flexible learning processes that may be structured based on time and location on an individual, customized basis (Tummons \& Ingleby, 2014). With distance education, universities are able to provide their educational services in a fast and economic manner not only to students in their own country, but around the world (Ruhe \& Zumbo, 2009). Offering distance education programs within higher education institutes has provided both students and teachers to construct flexible learning and teaching processes (DiStefano \& Witt, 2010).

The transformation within all social institutions have popularized new perspectives in the presentation of educational services. Regarding the development of competencies individuals may require in the future, the presentation of distance education services through new developing technologies has gained importance in educational policies (Simonson, Smaldino, Albright \& Zvacek, 2012).

In Turkey, many institutions conduct distance education and e-learning applications. "Inservice training", "orientation training" and "technical training" that demand expertise required by certain occupations are all conducted using distance education facilities today (Gulbahar, 2009, p. 31; Guler, 2017, p. 197). In Turkey, web based distance education applications are primarily conducted at "associate", "bachelor" and "postgraduate" levels in universities (Dincer, 2007, p. 10).

The purpose of this study is to present student occupancy rates between 2007 and 2016 of two-year associate degree distance education programs on the basis of both the program and the university and to identify the potential rates of change in Turkey. In accordance with this main purpose, the sub-problems below have been identified:

$>$ What is the overall situation of the programs in $\mathbf{1 0}$ years in terms of student occupancy?

$>$ What is the overall situation of the universities in $\mathbf{1 0}$ years in terms of student occupancy of the mentioned programs?

$>$ Do the rates of student occupancy of the programs significantly change with regard to the total number of years during which the programs have been opened and the number of universities?

$>$ Is there a significant relationship between the total number of years during which the programs have been opened and the number of universities?

$>$ Do the general occupancy rate of the universities significantly change as regards the total number of programs opened within the university and the total number of years during which the programs have been opened?

$>$ Is there a significant relationship between the total number of programs opened within the university and the total number of years during which the programs have been opened?

\section{METHOD}

The aim of this study is firstly to summarize the data in a descriptive way obtained without any interference and then reveal the relationship between the related variables. As mentioned by Punch \& Oancea (2014), this type of quantitative research which does not interfere in variables is of correlational survey type. Therefore, this research is of correlational survey type since the current situation has been explained through the relationship between variables without any interference. On the other hand, according to the quantitative research patterns classification made by McMillan \& Schumacher (2014), since the current situation is summarized without any interference, this study is of descriptive type, as well.

\section{Universe and Sample}

The universe of the research is composed of all the associate degree distance education programs in Turkey and the universities that have opened these programs. A total of 58 programs complying with these conditions have been opened between 2007 and 2016 and 
the number of universities serving these programs is 49 . The number of students of all these programs and universities have been used within the study. Therefore, the main and sole data of the study has been that of the universe and no selection has been made to identify a sample.

\section{Data Collecting Procedure}

The data of the study has been obtained from the number of quotas in the placement and additional placement guide published by the Centre of Assessment, Selection and Placement (CASP) between 2007 and 2016. One of the issues that has to be underlined here is the limitation of the data with only the mentioned years. In other words, the limitation of the study results from the fact that CASP has only published the data of the quotas between 2007 and 2016 . All the data for the 10-year period covered in this study is available through the links in the references provided below.

\section{Data Analysis}

First of all, the quotas of the related program have been determined for each year from the guide. Then additional quotas guide which has been published after final registration is completed has been examined.

Distance education programs that have available spaces have been identified and then occupancy rates have been determined by subtracting the number of available spaces from the total number of quotas for each department. These occupancy rates have been primarily calculated by identifying the overall average occupancy rate in the relevant university that opened a distance education program between 2007 and 2016. The overall average occupancy rate has been obtained through re-averaging the overall occupancy rate of a program for each year throughout universities. After the occupancy rates, the total number of years during which the programs have been opened and the total number of universities that opened a distance education program in $\mathbf{1 0}$ years' period have been calculated. In order to find an answer to the third and fourth sub-problems, the total number of years during which the programs have been opened have been categorized as "less than 5 years" and "more than 5 years". Similarly, the number of universities that have opened a distance education program have been categorized as "fewer than 3 universities" and "more than 3 universities" in order to balance the number of universities in categories. Thanks to these categorizations, the relationship between the overall occupancy rate and the number of years during which programs have been opened and the number of universities has been examined through Mann-Whitney $U$ test. In other words, the change in the occupancy rates has been statistically analyzed with regard to the total number of years during which the programs have been opened and the number of universities. The relationship between the total number of years and the number of universities has been examined through Chi-Square test.

After the programs-based analyses, the overall occupancy rates of each university has been calculated. In order to reach the result, the overall occupancy rate of all the programs opened within each university for each year has been calculated. There rates which have been obtained on yearly basis have been averaged by years and as a result the general occupancy rate of each university in terms of each year and program has been obtained. After this calculation, the total number of years during which each university has opened associate degree distance education program and the number of programs opened have been calculated. The variables of the number of years and programs opened have been grouped in such a way that the number of universities will be balanced in categories in order to answer the fifth and sixth sub-problems. Therefore, the universities have been split into two groups as "opened 4 or more programs" and "opened fewer than 4 programs". On the other hand, grouping by years has been done as "opened a program less than 5 years" and "opened a program for 5 and more years". After these categorizations, the relationship between the overall occupancy rate of universities and the variables of the number of programs opened and the total number of years during which programs opened has been examined via Mann-Whitney $U$ test. In other words, the change in the occupancy rates of mentioned programs at universities have been analyzed with regard to the number 
of programs opened and the number of years during which programs have been opened by using Mann-Whitney $U$ test. Besides, the relationship between the number of years during which universities have opened the programs and the total number of programs opened by each university has been examined through Chi-Square test. The descriptive analyses within the scope of this study were conducted with the Excel office program, while statistical analyses were conducted using the SPSS 20.0 package program.

\section{FINDINGS}

\section{Findings within the Context of Programs}

Table 1. Overall occupancy rates of the programs, the total number of years during which the programs have been opened and the number of universities

\begin{tabular}{|c|c|c|c|c|c|c|c|}
\hline Department & OR. \% & $\mathbf{N}$ & $\begin{array}{l}\text { NO } \\
\text { Uni. }\end{array}$ & Department & OR. \% & $\mathbf{N}$ & $\begin{array}{l}\text { No } \\
\text { Uni. }\end{array}$ \\
\hline $\begin{array}{l}\text { Disaster and Emergency } \\
\text { Management }\end{array}$ & 40.2 & 3 & 2 & Chemistry Technology & 47.3 & 3 & 1 \\
\hline $\begin{array}{l}\text { Jurisprudence/Jurisprudence } \\
\text { VS }\end{array}$ & 58.4 & 8 & 3 & $\begin{array}{l}\text { Control and Automation } \\
\text { Technology }\end{array}$ & 63.0 & 8 & 3 \\
\hline Hospitality Services & 63.4 & 1 & 3 & Cosmetics Technologies & 18.0 & 1 & 1 \\
\hline Culinary Arts & 26.8 & 4 & 2 & Logistics & 48.4 & 8 & 4 \\
\hline Banking and Insurance & 60.6 & 8 & 3 & Media and Communication & 32.5 & 5 & 3 \\
\hline Information Management & 43.7 & 6 & 7 & Mechatronics & 74.7 & 10 & 2 \\
\hline Computer Operator Training & 42.0 & 1 & 1 & Fashion Design & 45.7 & 4 & 2 \\
\hline Computer Programming & 60.8 & 10 & 34 & Accounting and Taxation & 43.7 & 9 & 10 \\
\hline Computer Technology & 73.0 & 3 & 1 & Forestry and Forest Products & 66.0 & 5 & 1 \\
\hline $\begin{array}{l}\text { Office M. and Executive } \\
\text { Assistant }\end{array}$ & 33.7 & 7 & 3 & Marketing & 58.4 & 5 & 2 \\
\hline Call Centre Services & 30.5 & 5 & 6 & $\begin{array}{l}\text { Retailing and Store } \\
\text { Management }\end{array}$ & 33.7 & 5 & 2 \\
\hline Child Development & 67.5 & 6 & 12 & Postal Services & 59.7 & 4 & 1 \\
\hline $\begin{array}{l}\text { Geographical Information } \\
\text { Systems }\end{array}$ & 49.8 & 7 & 3 & $\begin{array}{l}\text { Radio and TV Program } \\
\text { Production }\end{array}$ & 30.9 & 6 & 1 \\
\hline Foreign Trade & 54.4 & 7 & 7 & $\begin{array}{l}\text { Railroad Transportation } \\
\text { Management }\end{array}$ & 65.6 & 5 & 1 \\
\hline Pharmacy Services & 49.8 & 8 & 3 & Haircare and Beauty Services & 43.3 & 4 & 1 \\
\hline Electric & 67.6 & 4 & 3 & $\begin{array}{l}\text { Management of Healthcare } \\
\text { Inst. }\end{array}$ & 42.6 & 7 & 3 \\
\hline $\begin{array}{l}\text { Electronic Communication } \\
\text { Technology }\end{array}$ & 43.0 & 10 & 3 & $\begin{array}{l}\text { Medical Documentation and } \\
\text { Secret. }\end{array}$ & 70.6 & 8 & 7 \\
\hline Electronics Technologies & 62.9 & 8 & 3 & Medical Laboratory Techniques & 72.3 & 3 & 1 \\
\hline $\begin{array}{l}\text { Real Estate and Property } \\
\text { Management }\end{array}$ & 22.0 & 1 & 1 & $\begin{array}{l}\text { Medical Promotion and } \\
\text { Marketing }\end{array}$ & 37.9 & 3 & 2 \\
\hline Industrial Electronics & 44.0 & 2 & 2 & $\begin{array}{l}\text { Medical Promotion and } \\
\text { Secretarial }\end{array}$ & 8.0 & 1 & 1 \\
\hline Industrial Automation & 10.1 & 2 & 1 & Medicinal and Aromatic Plants & 45.7 & 3 & 1 \\
\hline $\begin{array}{l}\text { Food Quality Control and } \\
\text { Analysis }\end{array}$ & 31.5 & 3 & 1 & Tourist Guide & 53.0 & 3 & 2 \\
\hline Graphic Design & 25.7 & 5 & 1 & Tour Guiding & 79.6 & 1 & 1 \\
\hline Public Relations and Publicity & 50.5 & 6 & 3 & $\begin{array}{l}\text { Tourism and Hotel } \\
\text { Management }\end{array}$ & 33.1 & 9 & 4 \\
\hline Mapping and Cadastral Survey & 76.3 & 3 & 1 & Tourism and Travel Services & 63.0 & 1 & 1 \\
\hline $\begin{array}{l}\text { Human Resources } \\
\text { Management }\end{array}$ & 62.0 & 3 & 2 & $\begin{array}{l}\text { Applied English and } \\
\text { Translation }\end{array}$ & 49.7 & 3 & 2 \\
\hline $\begin{array}{l}\text { Internet and Network } \\
\text { Technologies }\end{array}$ & 60.7 & 6 & 3 & Web Technologies and Coding & 59.2 & 1 & 1 \\
\hline $\begin{array}{l}\text { Occupational Health and } \\
\text { Safety }\end{array}$ & 62.0 & 6 & 9 & Elderly Care & 66.7 & 2 & 1 \\
\hline Business Management & 43.9 & 10 & 17 & Local Governments & 34.8 & 4 & 1 \\
\hline
\end{tabular}


The data presented in the Table 1 respectively are 10 years occupancy rate for each program, how many years that the relevant program have been opened (at least by one university) and how many universities have opened the program. To exemplify, the overall average occupancy rate of the Disaster and Emergency Management program on the first line is $\mathbf{4 0 . 2 \%}$ throughout 10 years in the universities that have opened the program. The program has been opened 3 times and only by 2 universities.

When the data in the Table 1 has been analyzed, it is observed that the top three programs having the highest occupancy rate are Tour Guiding, Mapping and Cadastral Survey and Mechatronics, respectively. The average occupancy rates for these programs are more than $70 \%$. On the other hand, the last three programs having the least occupancy rates respectively are Medical Promotion and Secretarial, Industrial Automation and Cosmetics Technology. The occupancy rates of these programs are below $20 \%$.

When other columns in Table 1 are examined, it is observed that 22 programs have been opened by only one university in 10 years' period. The programs that have been opened by the highest number of universities are Computer Programming, Business Management and Child Development. While the number of universities opening these programs is more than 10, it is remarkable that the Computer Programming program has been opened by 34 universities.

According to the categorized variables of the number of years and universities, the number of programs which have been opened less than 5 years is 28 while this number increases up to $\mathbf{3 0}$ in more than 5 years category. On the other hand, the number of programs that have been opened by fewer than 3 universities are 33 while 25 programs have been opened by more than 3 universities. As a result of the Mann-Whitney $U$ test which has been carried out to determine the rate of change of overall occupancy rates of programs with regard to the total number of years during which they have been opened, there has found no significant relationship between the average occupancy rates of the programs and the total number of years that they have been opened $(U=439, p>.05)$. The visualized results of Mann-Whitney $U$ test have been presented below.

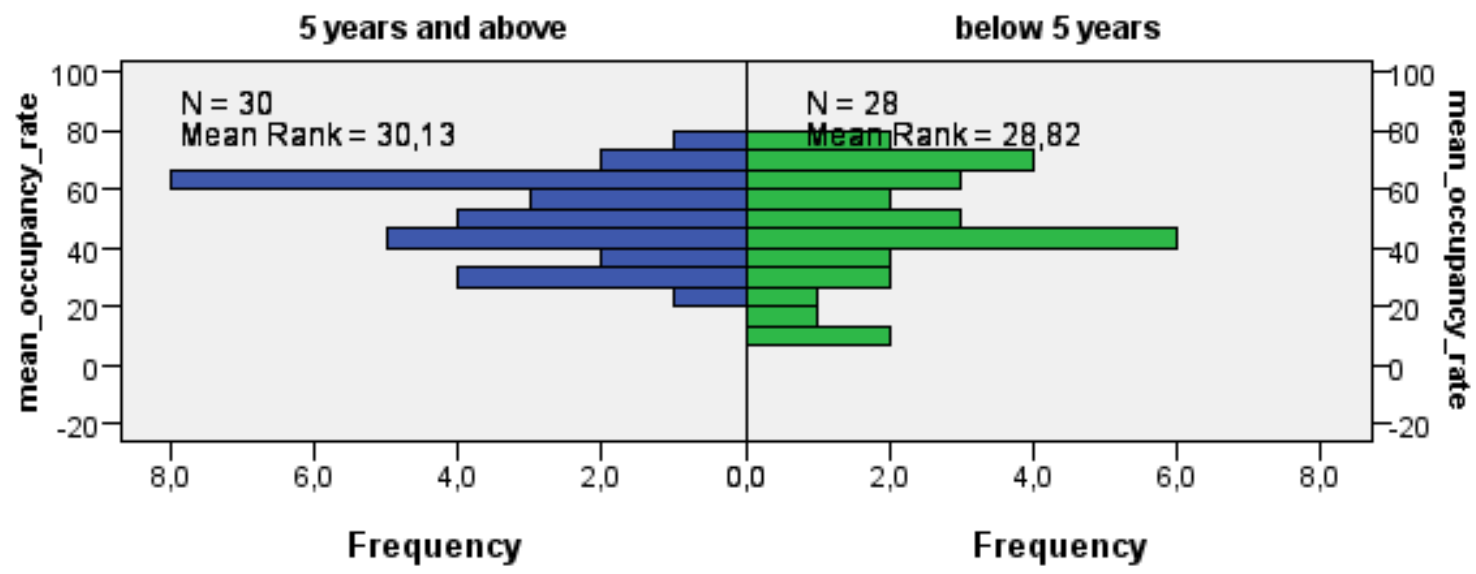

Figure 1. The visualised results of Mann-Whitney $U$ test

As observed in the diagram, there is not a statistical significance between the average occupancy rates of the programs and their mean sequence values for both the categories of less than 5 years and 5 years and more.

The results of Mann-Whitney $U$ test about the variances of mean occupancy rates of the programs with regard to the number of universities that they have been opened within have been insignificant $(U=464, p>.05)$, as well. The diagram of this test has been given below. It is observed in the diagram that as seen in the year variable, there has been no 
significant difference between the distributions of mean occupancy rates in the categories of the number of universities variable and mean sequences of this distribution.

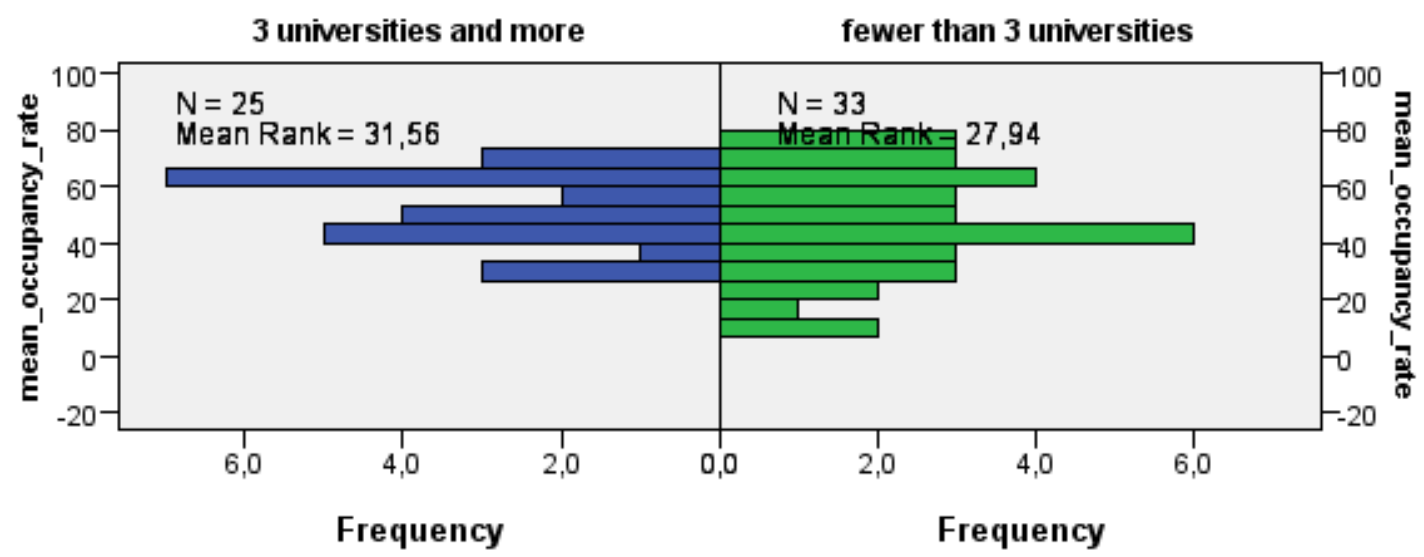

Figure 2. The results of Mann-Whitney $U$ test about the variances of mean occupancy rates of the programs with regard to the number of universities that they have been opened

The relationship between the number of years during which the programs have been opened and the categorized variable of the number of universities has been analyzed through Chi-Square test. There has found a significant relationship between the two variables as a result of this analysis $(x 2(1)=28.544, p<.001)$. This correlation could be clearly observed in Table 2 below.

Table 2. The number of universities and total number of years crosstab

\begin{tabular}{ccccc}
\hline & \multicolumn{2}{c}{ Number of Years } & \\
\cline { 3 - 4 } & Less than 5 & 5 and more & Total \\
\hline $\begin{array}{c}\text { Number } \\
\text { of Uni. }\end{array}$ & 26 & 7 & 33 \\
& Total & 2 & 23 & 25 \\
\hline
\end{tabular}

As observed in Table 2, of 33 programs opened by fewer than 3 universities, 26 programs have been opened for less than 5 years. By contrast, it is seen that the programs opened by 3 and more universities have been opened for 5 years and more. Therefore, it could be concluded that the programs opened by higher number of universities have also been opened for more years.

\section{Findings within the Context of Universities}

Table 3 below presents the data about the average occupancy rates of universities for all years and all the programs they have opened, the number of years during which they opened a program and the total number of programs opened within these years. For instance, the overall average occupancy rate of associate degree distance education programs within 10 years opened by Afyon Kocatepe University which is on the first line, has been found as $\mathbf{5 5 . 6 \%}$. The same university has opened a program for 8 years out of 10 and the total number of the opened programs is 7.

When the data has been examined in Table 3, it could be observed that Kafkas, Nevşehir Hacı Bektaş Veli and Celal Bayar Universities have the highest occupancy rates with over $\mathbf{7 0 \%}$. On the other hand, İstanbul Arel, İstanbul Bilgi and Cumhuriyet Universities have the lowest occupancy rates with less than $5 \%$ average. 
Table 3. The overall occupancy rates, the number of years during which a program has been opened and the total number of programs opened

\begin{tabular}{|c|c|c|c|c|c|c|c|}
\hline University & OR\% & $\mathbf{N}$ & $\begin{array}{l}\text { Prg. } \\
\text { N. }\end{array}$ & University & OR\% & $\mathbf{N}$ & $\begin{array}{l}\text { Prg. } \\
\text { N. }\end{array}$ \\
\hline \multicolumn{8}{|l|}{ Afyon Kocatepe } \\
\hline University & 55.6 & 8 & 7 & İstanbul Bilgi University* & 1.0 & 1 & 1 \\
\hline Akdeniz University & 40.5 & 6 & 3 & İstanbul Medipol University* & 10.2 & 1 & 3 \\
\hline Amasya University & $\mathbf{5 9 . 4}$ & 5 & 8 & İstanbul University & 58.1 & 7 & 8 \\
\hline Anadolu University & 45.6 & 5 & 7 & $\begin{array}{l}\text { Kafkas University } \\
\text { Kahraman Maraş Sütçü İmam }\end{array}$ & 81.4 & 1 & 1 \\
\hline Ankara University & 60.9 & 8 & 7 & University & 49.0 & 4 & 2 \\
\hline Atatürk University & 44.3 & 3 & 1 & Kapadokya Vocational School* & 60.6 & 3 & 3 \\
\hline Atılım University* & 18.8 & 9 & 4 & Karabük University & 48.4 & 7 & 8 \\
\hline Bahçeşehir University* & 13.5 & 4 & 3 & Karadeniz Technical University & 41.3 & 4 & 2 \\
\hline Balıkesir University & 14.9 & 2 & 3 & Kırıkkale University & 72.6 & 8 & 7 \\
\hline Bartın University & 35 & 1 & 1 & Kocaeli University & 60.0 & 7 & 5 \\
\hline $\begin{array}{l}\text { Beykent University* } \\
\text { Beykoz Logistics }\end{array}$ & 43.2 & 9 & 4 & Maltepe University* & 13.0 & 3 & 4 \\
\hline Vocational School* & 40.6 & 6 & 3 & Marmara University & 74.1 & 5 & 7 \\
\hline Bingöl University & 16.3 & 4 & 3 & Mehmet Akif Ersoy University & 45.7 & $\begin{array}{l}3 \\
1\end{array}$ & 1 \\
\hline $\begin{array}{l}\text { Bitlis Eren University } \\
\text { Çanakkale Onsekiz Mart }\end{array}$ & 62.9 & 6 & 2 & Mersin University & 46.1 & $\mathbf{0}$ & 16 \\
\hline University & 58.3 & 3 & 3 & $\begin{array}{l}\text { Muğla Sıtkı Koçman University } \\
\text { Nevşehir Hacı Bektaş Veli }\end{array}$ & 53.7 & 4 & 2 \\
\hline Celal Bayar University & 74.2 & 5 & 4 & University & 77.0 & 4 & 2 \\
\hline Çukurova University & 56.5 & 10 & 5 & Okan University* & 31.2 & 4 & 4 \\
\hline Cumhuriyet University & 4.0 & 1 & 1 & Ondokuz Mayıs University & 51.8 & 4 & 8 \\
\hline Dokuz Eylül University & 63.7 & 4 & 2 & Plato Vocational School* & 36.4 & $\begin{array}{l}6 \\
1\end{array}$ & 12 \\
\hline Erzincan University & 61.6 & 5 & 3 & Sakarya University & 69.4 & $\mathbf{0}$ & 9 \\
\hline Fırat University & 50.7 & 3 & 1 & Süleyman Demirel University & 48.6 & 9 & 6 \\
\hline Gazi University & 60.4 & 6 & 9 & $\begin{array}{l}\text { Trakya University } \\
\text { Turkish Logistics Research and }\end{array}$ & 51.7 & 9 & 4 \\
\hline $\begin{array}{l}\text { İnönü University } \\
\text { İstanbul Arel }\end{array}$ & 46.3 & 5 & 3 & Training Foundation* & 26.3 & 2 & 2 \\
\hline $\begin{array}{l}\text { University* } \\
\text { İstanbul Aydın }\end{array}$ & 1.0 & 1 & 1 & Uşak University & 9.0 & 4 & 2 \\
\hline University* & 35.2 & 9 & 7 & - & - & - & - \\
\hline
\end{tabular}

The analysis of the variance of the overall occupancy rate of universities with regard to the number of years during which universities have opened a program and the total number of programs opened within a university has been carried out with the help of categorised years and the number of year variables. As a result of the analyses, it has been concluded that 26 universities has opened fewer than 4 programs while those opening 4 and more programs has been found as 23 . According to the analysis of the number of universities by years, 24 universities has opened the programs for less than 5 years while the number of universities opening a program for 5 years and more has been found as 25 . It has been observed that there is not a significant relationship $(U=386, p>.05)$ between the occupancy rates of universities and the number of programs opened. The diagram of this test has been given below. 


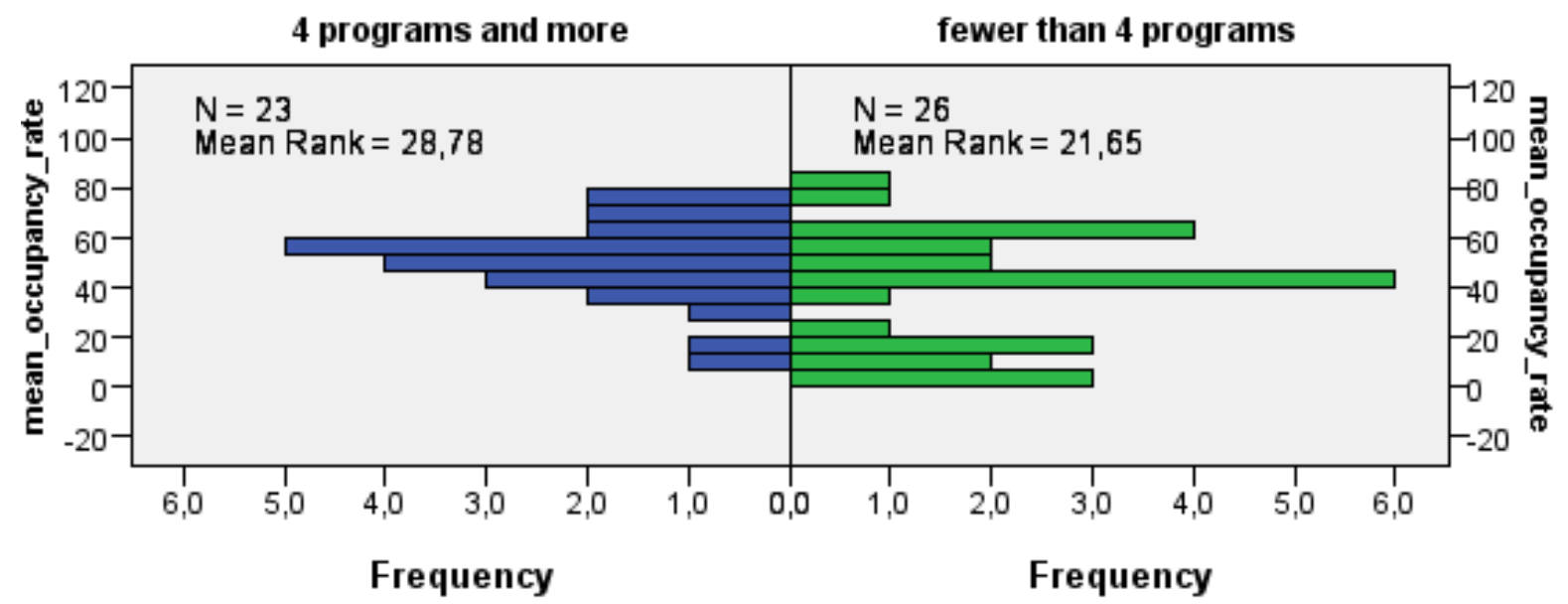

Figure 3. The distributions of the average occupancy rates of universities and mean sequences for the categories of programs

As seen in the diagram, there is not a significant difference between the distributions of the average occupancy rates of universities and mean sequences for the categories of fewer than 4 programs and 4 and more programs. Moreover, there has been found a significant difference $(U=429, p<.05)$ between the average occupancy rates of universities and the number of years during which they opened a program. The diagram of this test has been presented below.

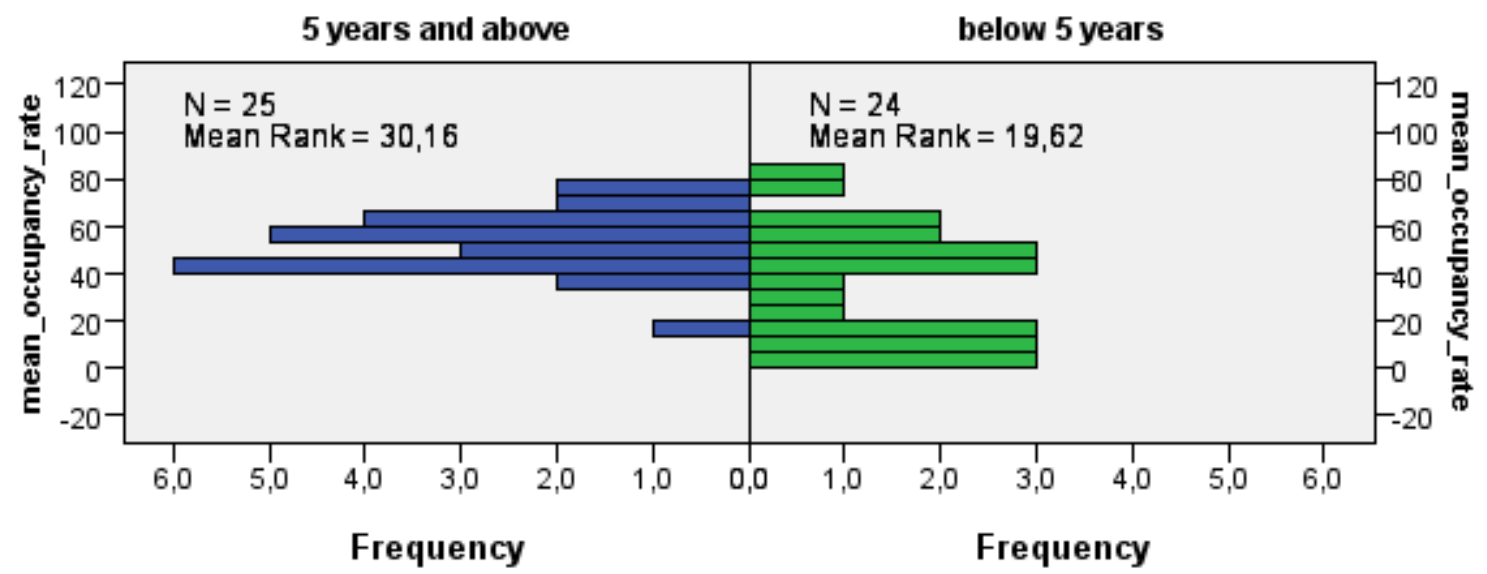

Figure 4. The average occupancy rates of the universities

It could be concluded from the data in the diagram that the average occupancy rates of the universities opening a program less than 5 years is lower in general while those having $50 \%$ and higher occupancy rates is located in 5 years and more category. This finding supports the argument that the universities opening a program for more years have higher occupancy rates.

Finally, the relationship between the number of programs opened by universities and the number of years during which the universities have opened a program has been analysed via Chi-Square test. As a result of this analysis, there has been found a significant relationship $(x 2(1)=22.4, p<.001)$ between the number of years during which the universities have opened a program and the number of programs opened. This significant relationship could be clearly seen in the crosstab below. According to the data in table, it could be concluded that 21 universities out of 24 opening a program for less than 5 years have opened fewer than 4 programs. On the other hand, of 25 universities opening a 
program for 5 years and more, 20 universities have opened 4 and more programs. Therefore, this result indicates that the universities opening a program for more years have also opened more programs.

Table 4. Crosstab of the number of programs opened and total number of years

\begin{tabular}{llccc}
\hline & & \multicolumn{2}{c}{ Number of programs } & \\
\cline { 3 - 4 } & $\begin{array}{c}\text { Fewer than } \\
\text { 4 programs }\end{array}$ & $\begin{array}{c}\text { 4 programs } \\
\text { and more }\end{array}$ & Total \\
\hline \multirow{2}{*}{ Year } & $\begin{array}{l}\text { Less than 5 } \\
\text { years }\end{array}$ & 21 & 3 & 24 \\
$\begin{array}{l}5 \text { years and } \\
\text { more }\end{array}$ & 5 & 20 & 25 \\
Total & 26 & 23 & 49 \\
\hline
\end{tabular}

The purpose of this study has been to analyse the occupancy rates between 2007 and 2016 of two-year associate degree distance education programs on the basis of both the program and the university and to identify the potential variances of the relevant occupancy rates. As a result of the analyses, 10 years' average occupancy rates of both the programs and universities has been descriptively presented. According to the statistical analyses, it has been concluded that program-based occupancy rates have not varied with regard to the number of years and the universities. It has also been concluded that university-based occupancy rates have not changed with regarding the number of programs that they opened though there is a significant difference with regard to the total number of years during which the universities opened a program.

\section{DISCUSSIONS and CONCLUSION}

The rapid development of information and communication technologies in the 21st century has great influence on all institutions around the world (Schmidt \& Cohen, 2014). People in the world come across new realities every day and this is a very ordinary situation any more. These new realities necessitate that students are equipped and nurtured with different and new qualifications to adapt education systems. In the meantime, students adapt themselves to the newly developed technologies and quickly start to use them. The fact that the ability of adapting to change is valid for educational institutions as well in these circumstances guide for reshaping of education policies (Solomon \& Schrum, 2010).

Distance education is one of the most popular terms in today's world. The educational institutions serving distance education to the society continuously develop new alternatives to in-class tuition in accordance with demands coming from students. The mobility of learners has increased thanks to the newly developed technologies and they have found an opportunity to reach knowledge always and everywhere. Individuals now have the opportunity to develop themselves quickly and on easy terms thanks to the distance education services having new technologies served by these new technologies (Martinez, 2014).

Mobile devices have started to be used in distance education services in parallel with the enabling effect served by these devices. The educational institutions have updated their policies to serve their services through mobile devices and this development have accelerated knowledge sharing between individuals and personal learning processes have substantially improved (Diehl, 2013).

Distance education institutions have to analyze the period of change experienced everywhere in the world and in this regard, the ability of change management of these institutions becomes an indispensable aspect. Besides, executives of distance education institutions need to designate the vision of their institutions in line with the period of change and should share this vision with students (Saylor, 2015). 
New developing technologies emphasize the important changes taking place in educational institutions. When considered regarding distance education institutions, the transformation process brought about by new technologies must be reevaluated in accordance with certain basic criteria. How distance education institutions are organized regarding new developing technologies, how distance education institutions are realizing their institutional missions, the number of students being provided distance education services, the course content offered in distance education services, "the support services " offered to students while providing distance education services, and the individual demand for the distance education programs they offer are some of these criteria (Moore \& Kearsley, 2012, p. 283).

Causalities such as the constant increase of individuals seeking self-development either through learning or personal development processes, the proliferation of lifelong learning in all sections of society, and the inability of individuals seeking self-development to abandon their current career environments have caused the constant increase in associate and bachelor level distance education programs (Sahin, 2017).

As a result of program based descriptive findings, it is observed that the programs having the lowest occupancy rate have been opened by only one university each. However, the fact that there is not a significant difference between the average occupancy rates of programs and the number of universities that opened these programs does not support the hypothesis that the programs opened by higher number of universities and thought as relatively more popular than others could have higher occupancy rate.

To put it in different way, there is not a significant difference between the occupancy rates of much known programs opened by higher number of universities and those of much specific programs opened by fewer number of universities. On the other hand, the average occupancy rates of the programs have not significantly differed with regard to the number of years during which they have been opened within the relevant years. As a matter of fact, this case supports the previously mentioned result in that there is not a significant difference between the occupancy rates of the programs which have been regularly opened for more years and those of rarely opened ones.

However, there has been found a significant relationship between the number of years during which the programs have been opened and the number of universities as a result of Chi-Square test. Depending on these relationship, it could be concluded that the programs that have been opened by higher number of universities have been opened for more years. Namely, the programs opened more frequently in specified years are those having more popularity and opened by higher number of universities. Nevertheless, it has been observed that this popularity has not made a difference on occupancy rates.

The descriptive analyses of universities have interestingly proved that the universities having much lower occupancy rates have opened only one program in one year. It could be concluded from this result that these universities have not achieved the anticipated results in terms of associate degree distance education programs and accordingly have not opened a program in later years.

The purpose of statistical analyses carried out on universities has been to test the hypothesis that regularly program-opening-universities for more years or those having higher number of programs significantly has higher occupancy rate. There has been found no significant difference between the number of programs opened and the occupancy rate of universities. Therefore, the findings has rejected the hypothesis arguing that the occupancy rate of universities opening higher number of programs and offering various associate degree distance education programs could be higher.

However, there is a significant difference in terms of the number of years during which programs have been opened and this result proves that the overall occupancy rates of universities which have opened programs for more years and have much experience in the 
field are higher than other universities. This finding may indicate that students opt for much experienced universities for higher education. On the other hand, Chi-Square analyses have indicated that more experienced universities have opened more programs while relatively younger universities have preferred to open fewer programs.

The programs analyzed within this study is limited to two years associate degree distance education programs. Therefore, it is recommended that future studies could focus on formal education associate degree programs and even bachelor's degree programs. Besides, the variances between the overall occupancy rates and more detailed information about universities may be examined and by this means much evidence-based information could be offered to shareholders. It is thought that the possible variation of occupancy rates may present more detailed information to students in their selection of university.

\section{BIODATA and CONTACT ADRESSES of AUTHOR}

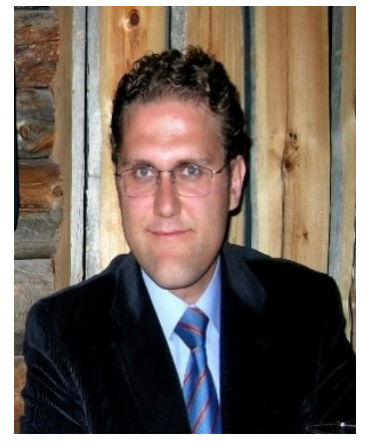

Dr. Eren KESIM is faculty member of the Anadolu University Faculty of Education, Department of Educational Sciences and Division of Educational Administration. He graduated from the Anadolu University Faculty of Economics and Administrative Sciences, Department of Economics in 2001. He continued to study at the Anadolu University Institute of Educational Sciences in the field of Educational Administration, Supervision, Planning and Economics and received his Master degree in 2004, and his doctorate degree in 2009. His academic research continues in the fields of economics of education, economics of distance education, educational administration, educational technology management and the training of school principals.

\section{Eren KESIM}

Anadolu University, Education Faculty, Yunusemre Campus, Eskisehir, Tepebasi, TURKEY

Tel: $+902223350580 / 3466$

E-mail: ekesim@anadolu.edu.tr

\section{REFERENCES}

Altbach, P.G, Reisberg, L., \& Rumbley, L.E. (2016). Tracking a global academic revolution. In Altbach P.G. (Ed.), Global perspectives on higher education (pp. 15-28). Baltimore: Johns Hopkins University Press.

Boys, J. (2015). Building better universities, Strategies, spaces, technologies, New York: Routledge.

Diehl, W. C. (2013). M-learning as a subfield of open and distance education. In Z.L. Berge, \& L.Y. Muilenburg (Eds.), Handbook of mobile learning (pp. 15-23). New York: Routledge.

Dincer, K. (2007). Turkiye'de internete dayali onlisans programlarinin yapici ogrenme ortamlari tasarimi acisindan degerlendirilmesine yonelik bir deneme [ A pilot study on evaluation of internet-based associate degree programs in Turkey interms designing constructivist learning environments]. (Master's dissertation). Anadolu University Graduate School of Social Sciences, Eskisehir, Turkey. Available from the Council of Higher Education, National Dissertation Center, Dissertation ID: 205918. Retrieved September 17, 2017 from https: //tez.yok.gov.tr/UlusalTezMerkezi/TezGoster?key=ePX_SaJ0b35Gq45swK G3IOxhQEhwZ6ZJUOYDqp50lkwdEpRIzuYfEHHqOXrcVLTa

DiStefano, A., \& Witt, J. (2010). Leadership and management of online learning environments in universities. In K.E.Rudestam, \& J.Schoenholtz-Read (Eds.), Handbook of online learning (2nd ed., pp. 404-422). Thousand Oaks, California: Sage Publications. 
Ferguson, R., Sharples, M., \& Beale, R. (2015). MOOCs 2030. A Future for massive online learning. In C.J.Bonk, M.M.Lee, T.C.Reeves, \& T.H. Reynolds (Eds.), MOOCs and open education around the world (pp.315-326). New York \& London: Routledge.

Gulbahar, Y. (2009). e-ogrenme [e-learning]. Ankara: Pegem Akademi.

Guler, E. (2017). İs yasaminda acik ve uzaktan ogrenmenin rolu [The role of open and distance learning in professional life]. In T.V. Yuzer(Ed.), Acik ve uzaktan ogrenmede bireysel farkliliklar [Individual differences in open and distance learning] (pp.187-204). Eskisehir: Anadolu Universitesi Yayinlari.

Huang, X., Hsiao, E-L., \& Lunce, L. (2014). Professional development and training for distance instructors in higher education. In A. A. Piña, \& A.P. Mizell (Eds.), Reallife distance education. Case studies in practice (pp.359-376). Charlotte, NC: IAPInformation Age Publishing.

Martinez, B. (2014). Distance learning. In D. J. Brewer \& L.O. Picus (Eds.), Encyclopedia of education economics and finance (Volume: I, pp. 212-215). Thousand Oaks, California: Sage Publications.

McMillan, J., \& Schumacher, S. (2014). Research in education: Evidence-based inquiry (7th ed.). Essex: Pearson Education.

Moore, M.G., \& Kearsley, G. (2012). Distance education: A systems view of online learning (3rd ed.). Belmont, California: Wadsworth Cengage Learning.

OSYM. (2007). Yuksekogretim programlari ve kontenjanlari kilavuzu [Higher education student placement guidebook]. Retrieved January 13, 2017 from http: / / www.osym.gov.tr/TR,1328/2007.html

OSYM. (2007). Yuksekogretim programlarina ek yerlestirme kilavuzu [Guidebook for higher education programs of matriculation for reserves]. Retrieved January 13, 2017 from http: / /www.osym.gov.tr/TR,1328/2007.html

OSYM. (2008). Yuksekogretim programlari ve kontenjanlari kilavuzu [Higher education student placement guidebook]. Retrieved January 13, 2017 from http: / / www.osym.gov.tr/TR,1209/2008.html

OSYM. (2008). Yuksekogretim programlarina ek yerlestirme kilavuzu [Guide for higher education programs of matriculation for reserves]. Retrieved January 13, 2017 from http://www.osym.gov.tr/TR,1209/2008.html

OSYM. (2009). Yuksekogretim programlari ve kontenjanlari kilavuzu [Higher education student placement guidebook]. Retrieved January 13, 2017 from http: / / www.osym.gov.tr/TR,1168/2009.html

OSYM. (2009). Yuksekogretim programlarina ek yerlestirme kilavuzu [Guide for higher education programs of matriculation for reserves]. Retrieved January 13, 2017 from http://www.osym.gov.tr/TR,1168/2009.html

OSYM. (2010). Yuksekogretim programlari ve kontenjanlari kilavuzu [Higher education student placement guidebook]. Retrieved January 13, 2017 from http://www.osym.gov.tr/TR,1112/2010.html

OSYM. (2010). Yuksekogretim programlarina ek yerlestirme kilavuzu [Guide for higher education programs of matriculation for reserves]. Retrieved January 13, 2017 from http: //www.osym.gov.tr/TR,1112/2010.html

OSYM. (2011). Yuksekogretim programlari ve kontenjanlari kilavuzu [Higher education student placement guidebook]. Retrieved January 13, 2017 from http: / / www.osym.gov.tr/TR,1011/2011.html

OSYM. (2011). Yuksekogretim programlarina ek yerlestirme kilavuzu [Guide for higher education programs of matriculation for reserves]. Retrieved January 13, 2017 from http://www.osym.gov.tr/TR,1011/2011.html 
OSYM. (2012). Yuksekogretim programlari ve kontenjanlari kilavuzu [Higher education student placement guidebook]. Retrieved January 13, 2017 from

http://www.osym.gov.tr/TR,925/2012.html

OSYM. (2012). Yuksekogretim programlarina ek yerlestirme kilavuzu [Guide for higher education programs of matriculation for reserves]. Retrieved January 13, 2017 from http://www.osym.gov.tr/TR,925/2012.html

OSYM. (2013). Yuksekogretim programlari ve kontenjanlari kilavuzu [Higher education student placement guidebook]. Retrieved January 13, 2017 from http://www.osym.gov.tr/TR,870/2013.html

OSYM. (2013). Yuksekogretim programlarina ek yerlestirme kilavuzu [Guide for higher education programs of matriculation for reserves]. Retrieved January 13, 2017 from http://www.osym.gov.tr/TR,870/2013.html

OSYM. (2014). Yuksekogretim programlari ve kontenjanlari kilavuzu [Higher education student placement guidebook]. Retrieved January 13, 2017 from http://www.osym.gov.tr/TR,851/2014.html

OSYM. (2014). Yuksekogretim programlarina ek yerlestirme kilavuzu [Guide for higher education programs of matriculation for reserves]. Retrieved January 13, 2017 from http://www.osym.gov.tr/TR,851/2014.html

OSYM. (2015). Yuksekogretim programlari ve kontenjanlari kilavuzu [Higher education student placement guidebook]. Retrieved January 13, 2017 from http: //www.osym.gov.tr/TR,45/2015.html

OSYM. (2015). Yuksekogretim programlarina ek yerlestirme kilavuzu [Guide for higher education programs of matriculation for reserves]. Retrieved January 13, 2017 from http://www.osym.gov.tr/TR,45/2015.html

OSYM. (2016). Yuksekogretim programlari ve kontenjanlari kilavuzu [Higher education student placement guidebook]. Retrieved January 13, 2017 from http: / / www.osym.gov.tr/TR,9292/2016.html

OSYM. (2016). Yuksekogretim programlarina ek yerlestirme kilavuzu [Guide for higher education programs of matriculation for reserves]. Retrieved January 13, 2017 from http://www.osym.gov.tr/TR,9292/2016.html

Punch, K.F., \& Oancea, A. (2014). Introduction to research methods in education (2nd ed.). Los Angeles, California: Sage Publications.

Ruhe, V., \& Zumbo, B.D. (2009). Evaluation in distance education and e-learning. New York: The Guilford Press.

Sahin, T. (2017). Anadolu Universitesi acikogretim sisteminin tarihsel gelisimi [The historical development of the Anadolu University open education system]. Eskisehir: Anadolu Universitesi Yayinlari.

Saylor, A. (2015). Faculty development needs for distance education. In G. Eby \& T.V. Yuzer (Eds.), Indentification, evaluation and perceptions of distance education experts (pp. 249-263). Hershey, PA: Information Science Reference.

Schmit, E., \& Cohen, J. (2014). The new digital age. Transforming nations, businesses and our lives. New York: Vintage Books.

Simonson, M., Smaldino, S., Albright, M., \& Zvacek, S. (2012). Teaching and learning at a distance: Foundations of distance education (5th ed.). Boston, MA: Pearson Education.

Solomon, G., \& Schrum, L. (2010). Web 2.0: How-to for educators. Eugene, Oregon: International Society for Technology in Education.

Tummons, J., \& Ingleby, E. (2014). A-Z of lifelong learning. Maidenhead: Open University Press. 